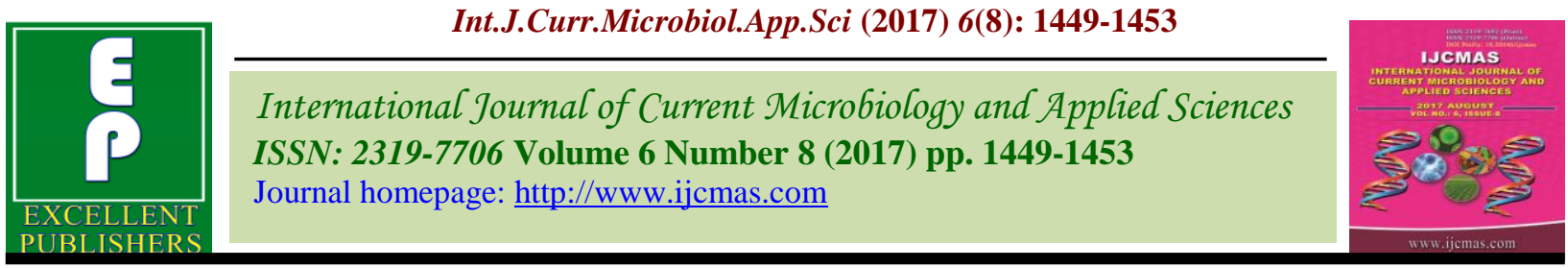

Original Research Article https://doi.org/10.20546/ijcmas.2017.608.175

\title{
Stenting: A Technique for Rapid Multiplication of Peach (Prunus persica L. Batsch) Plants
}

\author{
J.S. Brar* and Savreet Khehra \\ Department of Fruit Science, PAU, Ludhiana-141001, Punjab, India \\ *Corresponding author
}

A B S T R A C T

Keywords

IBA, Peach, Sharbati, Stenting.

Article Info

Accepted:

17 June 2017

Available Online:

10 August 2017
The experiment was carried out with the aim of rapid propagation of peach (Prunus persica L. Batsch) plants. The 18 and $24 \mathrm{~cm}$ long stem cuttings of peach cv. Sharbati were used as rootstock and peach cv. Shan-e-Punjab was used as scion. The stents i.e. cuttings of rootstock simultaneously tongue grafted with scion cultivar after treatments of IBA (Indole-3-butyric acid viz. 0, 500, 1000, 1500 and $2000 \mathrm{mgl}^{-1}$ were planted in last week of December, $1^{\text {st }}, 2^{\text {nd }}, 3^{\text {rd }}$ week of January. Stents made by using $24 \mathrm{~cm}$ long cuttings of rootstock treated with higher doses of IBA and planted during $1^{\text {st }}$ and $2^{\text {nd }}$ week of January exhibited higher success and better plant growth.

\section{Introduction}

The peach (Prunus persica L. Batsch) is the third most important fruit crop grown commercially after apple and pear in the temperate zones of world with total production of 20.0 million MT (USDA, 2016). In India, peach cultivation is confined to the warm temperate and sub-tropical parts of Jammu and Kashmir, Himachal Pradesh, Punjab, Haryana, Uttrakhand, parts of Uttar Pradesh and Tamil Nadu. In Punjab, peach cultivation is making headway with the introduction of low chilling, early ripening and superior quality cultivars from Florida and Texas. The varieties like Partap, Shan-iPunjab, Florida Prince and Earligrande have become very popular and are grown commercially in Punjab over an area of 1763 ha with an annual production of 31318 MT
(Anonymous, 2016). However, the limited availability of sufficient planting material is a major constraint for the slow pace of area coverage under peach in this region. Peach is generally propagated through tongue grafting and T-budding using 'Sharbati' or 'Fordaguard' seedlings as a rootstock. It takes almost two years to develop a saleable plant by following existing way of plant propagation. Stenting is a method of rapid multiplication of plants (Van De Pol, 1982). The word stenting is derived from Dutch word 'stenting' which means 'to stem'. It is a combination of 'stekken' means 'to strike a cutting' and 'enter' means 'to graft'. In this method cutting and grafting is performed simultaneously. The scion is grafted onto nonrooted rootstock cuttings. The formation of 
the union and adventitious roots on the rootstock occurs simultaneously. Stenting is now being used in many ornamental and fruit crops. Stenting has become an important method of fast multiplication in rose (Nazari et al., 2009) and even being used for apple, plum and pear (Hartman et al., 2002). Stenting in sweey cherry onto Colt and Baggugosha onto Quince A could shorten the nursery production duration to one season under protected structures (Negi and Upadhyay, 2016). The root initiation on the rootstock is of supreme significance for successful graft union. In hard wood peach cuttings, it is difficult to root, hence; the rooting hormone IBA is used to induce rooting as IBA associated with cell division stimulated by the auxin at the graft union. The stents made from scion variety semisoft pear (Pyrus communis L. X Pyrus pyrifolia Burm F.) grafted on the cuttings of rootstock 'Kainth' (Pyrus pashia Hamilton) after third week of January using higher doses of IBA exhibited higher success using this technique (Brar and Gill, 2014).

Similarly, IBA application produced the maximum lateral shoots, internodes length, root length and root number in both nonrooted and rooted stocks in stents made from sweet cherry and Colt (Negi and Upadhyay, 2016). Kaur et al., (2015) also reported similar results with IBA 3000 ppm treatment in peach. Iqbal et al., 1999 and Davin et al., 2011 also reported similar findings in Apple rootstocks. Length of stem cutting has significant effect on survival rate and root development in Asian pear (Jana et al., 2014). Similarly, the time of planting of stents may significantly influence the success in propagation through stenting. Brar and Gill (2014) recorded higher success in stenting in pear performed in late January under NorthIndian plains. Therefore, to reduce the time for multiplication of peach nursery plants on suitable rootstock, the preset investigations were carried out at Regional Research Station, Punjab Agricultural University Bathinda (Punjab).

\section{Materials and Methods}

This study was conducted at Regional Research Station, Punjab Agricultural University, Bathinda (Punjab) in open field conditions. Pencil thickness stem cuttings of 18 and $24 \mathrm{~cm}$ length of 6-year old 'Sharbati' peach (Prunus persica L. Batsch) were used as rootstock and the peach cv. 'Shan-i-Punjab of similar age was used as a scion. The grafting of scion on rootstock was done with 'Tongue grafting' method. After making stents i.e. insertion of scion stick on to the cuttings of rootstock, the union was wrapped with the polythene tape tightly. The lower portion of cuttings was dipped in different concentrations of Indole-3-butyric acid (IBA) viz. 0 and 500, 1000, 1500 and $2000 \mathrm{mgl}^{-1}$ for 2-3 minutes. The stents were made and planted at weekly interval i.e. last week of December, $1^{\text {st }}, 2^{\text {nd }}$ and $3^{\text {rd }}$ week of January. The planting of stent was made in such a manner that more 60 per cent of rootstock was inside the soil. Twelve stents were prepared and planted for three replications of each treatment. The soil was kept moist throughout the experimental time. Successful propagation was determined in the formation of the graft union, survival rate after bud take, plant height and root growth. The survival of stents was recorded in the last week of March when the vegetative bud/shoots started wilting in unsuccessful stents due to failure of root development in such stents. The fresh root length and plant height was recorded when the plants become deciduous in the following winter i.e. in the month of January.

\section{Results and Discussion}

The results indicated that the length of stem cuttings, IBA concentration and time of 
planting significantly influence the stenting success in peach. The results also exposed that the significant effect of the interaction between the length of stem cuttings, time of stenting and IBA concentration on successful graft union formation. Among treatments of IBA, higher dose of IBA (1500 and $2000 \mathrm{mgl}^{-}$ ${ }^{1}$ ) exhibited higher success with highest mean success $(33.34 \%)$ in $2000 \mathrm{mgl}^{-1}$ treatments followed by $30.56 \%$ in $1500 \mathrm{mgl}^{-1}$ treatment, while it was least $(8.58 \%)$ in untreated stents (Table 1). The mean length of roots was also highest $(50.16 \mathrm{~cm})$ in $2000 \mathrm{mgl}^{-1}$ treatments followed by $47.09 \mathrm{~cm}$ in $1500 \mathrm{mgl}^{-1}$ treatment and it was minimum in untreated cuttings.

Likewise, the highest plant height (152.07 $\mathrm{cm})$ was recorded in higher dose $\left(2000 \mathrm{mgl}^{-1}\right)$ of IBA. Longer cuttings performed better with respect to plant success and root growth
(Table 2), while plant height (Table 3) was comparatively higher in smaller cuttings. Significantly higher survival rate $(24.68 \%)$ and root length $(44.75 \mathrm{~cm})$ was recorded in longer cuttings than $21.02 \%$ survival and $40.75 \mathrm{~cm}$ root length in smaller cuttings. However, plant height was non-significantly higher in smaller cuttings. The date of preparation and planting of stents also influenced the success of stenting. The stents planted during $2^{\text {nd }}$ and $3^{\text {rd }}$ week of January recorded mean highest 28.82 and $27.78 \%$ success, respectively. The mean length of roots was also found highest (48.38 and 48.15 $\mathrm{cm})$ planted in $2^{\text {nd }}$ and $3^{\text {rd }}$ week of January. The stents planted during $2^{\text {nd }}$ week of January also exhibited higher plant height. Interaction among IBA treatment, root and shoot growth was also found significant with respect to root growth.

Table.1 Effect of length of stem cuttings, date of stenting and

IBA treatments on plant success (\%)

\begin{tabular}{|c|c|c|c|c|c|c|c|c|c|}
\hline \multirow[b]{4}{*}{ Treatments(T) } & \multicolumn{8}{|c|}{ Length $(\mathrm{L})$ of stem cuttings $(\mathrm{cm})$} & \multirow[b]{4}{*}{ Mean $(\mathbf{T})$} \\
\hline & \multicolumn{4}{|c|}{18} & \multicolumn{4}{|c|}{24} & \\
\hline & \multicolumn{8}{|c|}{ Date of stenting (D) } & \\
\hline & D-1 & D-2 & D-3 & D-4 & D-1 & D-2 & D-3 & D-4 & \\
\hline 0 & 8.33 & 8.31 & 8.31 & 8.31 & 7.97 & 7.97 & 8.33 & 11.11 & 08.58 \\
\hline 500 & 7.78 & 13.89 & 19.44 & 13.89 & 19.44 & 25.00 & 22.22 & 19.44 & 17.64 \\
\hline 1000 & 19.44 & 25.00 & 25.00 & 19.44 & 25.00 & 30.56 & 27.78 & 22.22 & 24.31 \\
\hline 1500 & 22.22 & 30.56 & 33.33 & 30.56 & 25.00 & 38.89 & 38.89 & 25.00 & 30.56 \\
\hline 2000 & 27.78 & 38.89 & 33.33 & 27.78 & 25.00 & 41.67 & 41.67 & 30.56 & 33.34 \\
\hline Mean (D) & 17.11 & 23.33 & 23.88 & 20.00 & 20.48 & 28.82 & 27.78 & 21.67 & 22.88 \\
\hline Mean (L) & \multicolumn{4}{|c|}{21.02} & \multicolumn{4}{|c|}{24.68} & \\
\hline $\mathrm{LSD}(\leq 0.5)$ & \multicolumn{2}{|c|}{ L: 1.86} & \multicolumn{2}{|r|}{ D: 2.63} & \multicolumn{3}{|c|}{ T: 2.94} & \multicolumn{2}{|c|}{ LxDxT : 8.32} \\
\hline
\end{tabular}

Table.2 Effect of length of stem cuttings, date of stenting and

IBA treatments on root growth $(\mathrm{cm})$

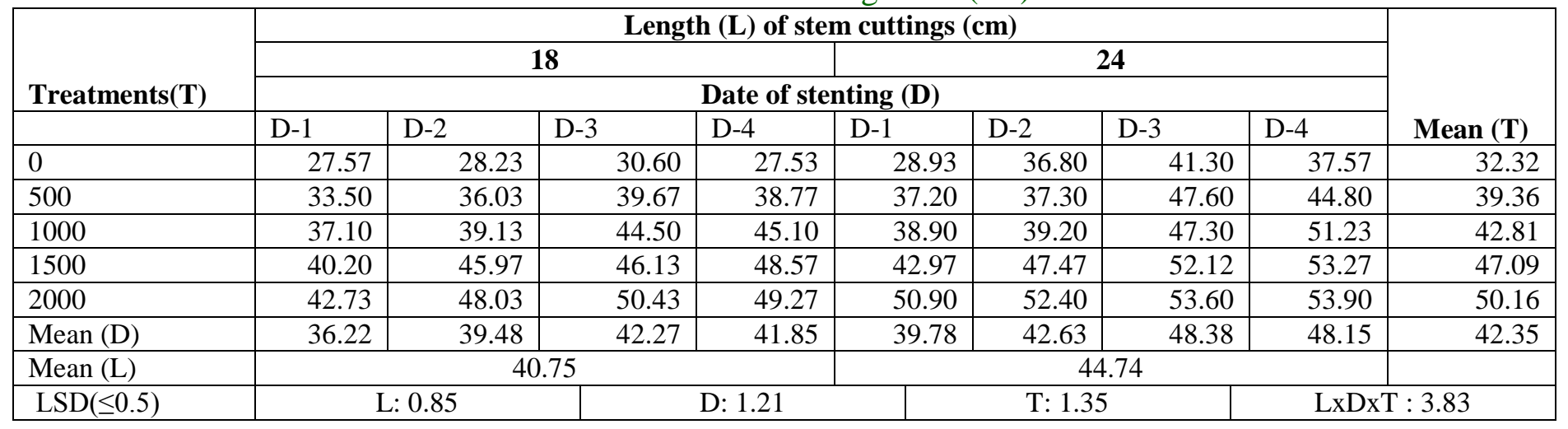


Table.3 Effect of length of stem cuttings, date of stenting and

IBA treatments on plant height $(\mathrm{cm})$

\begin{tabular}{|c|c|c|c|c|c|c|c|c|c|}
\hline \multirow[b]{4}{*}{ Treatments(T) } & \multicolumn{8}{|c|}{ Length (L) of stem cuttings $(\mathrm{cm})$} & \multirow[t]{4}{*}{ Mean (T) } \\
\hline & \multicolumn{4}{|c|}{18} & \multirow{2}{*}{\multicolumn{4}{|c|}{ ting (D) }} & \\
\hline & \multicolumn{4}{|c|}{ Date of stenting (D) } & & & & & \\
\hline & D-1 & D-2 & D-3 & D-4 & D-1 & $\mathrm{D}-2$ & D-3 & D-4 & \\
\hline 0 & 74.47 & 95.50 & 99.83 & 92.67 & 89.00 & 88.23 & 97.47 & 95.90 & 91.63 \\
\hline 500 & 120.67 & 126.00 & 135.33 & 131.67 & 120.73 & 120.23 & 127.77 & 121.77 & 125.52 \\
\hline 1000 & 128.67 & 134.33 & 134.67 & 138.67 & 122.17 & 138.23 & 135.23 & 136.03 & 133.50 \\
\hline 1500 & 140.33 & 145.67 & 148.67 & 144.00 & 139.33 & 151.53 & 148.97 & 147.03 & 145.69 \\
\hline 2000 & 146.00 & 154.00 & 152.33 & 148.00 & 149.13 & 159.80 & 155.73 & 151.53 & 152.07 \\
\hline Mean (D) & 122.03 & 131.10 & 134.17 & 131.00 & 124.07 & 131.60 & 133.03 & 130.45 & 129.68 \\
\hline Mean (L) & \multicolumn{4}{|c|}{131.15} & \multicolumn{4}{|c|}{129.07} & \\
\hline $\operatorname{LSD}(\leq 0.5)$ & \multicolumn{3}{|c|}{ L: NS } & D: 2.68 & \multicolumn{3}{|c|}{$\mathrm{T}: 2.99$} & \multicolumn{2}{|c|}{ LxDxT : 8.47} \\
\hline
\end{tabular}

Among all the treatments maximum success (41.67\%) was recorded when 24 long cutting treated with $2000 \mathrm{mgl}^{-1}$ IBA and planted in the second and third week of January. Longer cuttings treated with $2000 \mathrm{mgl}^{-1}$ IBA and planted in $4^{\text {th }}$ week of January produced maximum root growth $(53.60 \%)$ among all the treatments. Similarly, maximum height of $159.80 \mathrm{~cm}$ was recorded with IBA $\mathrm{mgl}^{-1}$ treatment of $24 \mathrm{~cm}$ long cuttings planted during $2^{\text {nd }}$ week of January.

The IBA treatments, time of planting stents and length of rootstock cuttings significantly influenced the success of stenting in peach. IBA being a root inducer significantly improve the survival and success of stents particularly at higher dose. Štefančič et al., (2005) also reported IBA induced stronger shoot growth and the development of acrobasal type of the rooting system in 'GiSelA 5' the dwarfing cherry rootstock.

The best dose for propagation of GF-655 peach rootstock through cuttings was 2500 ppm IBA (Ahmad et al., 2003). However, Tewfik (2002) observed 6000 ppm IBA for highest rooting percentage in 'Nemaguard' peach rootstock. Negi and Upadhyay (2016) obtained maximum stentling height in sweet cherry and Baggugosha in 5000 ppm IBA application. The high success in longer cuttings may be due to deep planting and better contact of hard wood cuttings to the soil leading to higher rooting and success rate. Aminah et al., (2015) also recorded higher rooting in longer cuttings of Tinospora crispa among three cutting lengths of $7.5 \mathrm{~cm}, 15 \mathrm{~cm}$ and $22.5 \mathrm{~cm}$ 2015. However, maximum success in Asian pear (Pyrus pyrifolia L) was recorded in smaller cuttings but shoot growth was recorded in smaller cutting among 15, 20 and $25 \mathrm{~cm}$ long cuttings (Jana et al., 2015). The time of preparation and planting of stents also affect the survival and success of stenting. The survival of stents planted in the last week December may be due drying of stents owing to cold temperature exposure for longer period and in the third week of January, it may be due to limited period of development of callus on the cut ends and sprouting of vegetative buds.

The survival was significantly reduced in all the treatments due to failure in development of roots. Brar and Gill (2014) recorded higher success and root length in the stents of pear planted late in $3^{\text {rd }}$ week of January followed by $4^{\text {th }}$ week of January. The stenting technique in results fast multiplication of plants in peach and we can produce grafted plants in a year in comparison to two years with existing practice. However, the success in the stenting technique of propagation is low and further investigations to improve the success may be carried out. 


\section{References}

Ahmed, M.S., N.A. Abbasi and Muhammad, A. 2003. Effects of IBA on Hardwood Cuttings of Peach Rootstocks under Greenhouse Conditions. Asian J. Plant Sci. (2): 265-269.

Aminah, H., M. S. Ahmad Fauzi, Tariq, M. and Hamzah, M. 2015. Effect of hormone and cutting length on the rooting of Tinospora crispa, Int. J. Scientific and Res. 5 (3): 1-4.

Anonymous, Package of practices for cultivation of Fruits 2016. Punjab Agricultural University, Ludhiana, pp.74.

Brar, J. S. and Gill, M. S. 2014. Rapid propagation of pear through stenting. $J$. Res. Punjab agric. Univ. 51 (1): 33-35.

Davin, S.R., E.G. Moghadam and Kiani, M. 2011. Rooting response of hardwood cuttings of MM111 apple clonal rootstock to indolebutyric acid and rooting media. Asian J. Applied Sci. (4): 453-458.

Hartman, H. T., D. E. Kester and Davis, F. T. 2002. Plant propagation: Principle and Practice. Prentice Hall.

Iqbal, M., F., A. Subhan, K. Gafoor, Aseem and Zilzni, M. S. 1999. Effect of different concentrations of Indole Butyric Acid (IBA) on root initiation and plant survival of apple cuttings. $J$. Biol. Sci., 2(4), 1314-1316.

Jana, B. R., B. Das and Kumar, S. 2015. Efficacy of IBA and determination of cuttings size in Asian pear (Pyrus pyrifolia L.). International J Plant Res., 2015, 5, 3, 64-67.

Kaur, S. 2015. Effect of different treatments of Indole-3-butyric acid (IBA) on the rooting and growth performance of hardwood cuttings of peach (Prunus persica L. Batch). Agricultural Sci. Digest. (35): 41-45.

Nazari, F., M. Khosh-Khui and Salehi, H. 2009. Growth and flower quality of four Rosa hybrid L. cultivars in response to propagation by stenting or cutting in soilless culture. Scienitia. Hort. (119): 302-305.

Negi, N.D. and Upadhyay, S.K. 2016. Stenting -A new technique for sweet cherry and pear propagation under polyhouse conditions. Indian J Hort. 73 (2):296-298.

Štefančič1, M., F. Štampar and Osterc, G. 2005. Influence of IAA and IBA on root development and quality of Prunus'GiSelA 5' leafy cuttings. Hort. Science, 40 (7):2052-2055.

Tewfik, A. A. 2002. Effect of IBA, planting media and type of cutting on rooting of 'Nemaguard' peach rootstock under Egyptian conditions. Acta Hort. (592): 169-175.

U.S.D.A., Fresh Peaches and Cherries: World Markets and Trade. Foreign Agricultural Service September, 2016 Report.

Van De Pol, P. A. and Breukelaar, A. 1982. Stenting of rose; a method for quick propagation by simultaneously cutting and grafting. Scientia Hort. 17(2): 187196.

\section{How to cite this article:}

Brar, J.S. and Savreet Khehra. 2017. Stenting: A Technique for Rapid Multiplication of Peach (Prunus persica L. Batsch) Plants. Int.J.Curr.Microbiol.App.Sci. 6(8): 1449-1453. doi: https://doi.org/10.20546/ijcmas.2017.608.175 